This is the author's final, peer-reviewed manuscript as accepted for publication. The publisher-formatted version may be available through the publisher's web site or your institution's library.

\title{
Exploring the distribution of park availability, features, and quality across Kansas City, Missouri by income and race/ethnicity: an environmental justice investigation
}

Katherine B. Vaughan, Andrew T. Kaczynski, Sonja A. Wilhelm Stanis, Gina M. Besenyi, Ryan Bergstrom, \& Katie M. Heinrich

\section{How to cite this manuscript}

If you make reference to this version of the manuscript, use the following information:

Vaughan, K. B., Kaczynski, A. T., Wilhelm Stanis, S. A., Besenyi, G. M., Bergstrom, R., \& Heinrich, K. M. (2013). Exploring the distribution of park availability, features, and quality across Kansas City, Missouri by income and race/ethnicity: An environmental justice investigation. Retrieved from http://krex.ksu.edu

\section{Published Version Information}

Citation: Vaughan, K. B., Kaczynski, A. T., Wilhelm Stanis, S. A., Besenyi, G. M., Bergstrom, R., \& Heinrich, K. M. (2013). Exploring the distribution of park availability, features, and quality across Kansas City, Missouri by income and race/ethnicity: An environmental justice investigation. Annals of Behavioral Medicine, 45(Suppl 1), S28S38.

Copyright: (c) The Society of Behavioral Medicine 2012

Digital Object Identifier (DOI): doi:10.1007/s12160-012-9425-y

Publisher's Link: http://link.springer.com/article/10.1007/s12160-012-9425-y

This item was retrieved from the K-State Research Exchange (K-REx), the institutional repository of Kansas State University. K-REx is available at http://krex.ksu.edu 
Exploring the distribution of park availability, features, and quality across Kansas City, Missouri by income and race/ethnicity: An environmental justice investigation

\begin{abstract}
Background: Parks are key community assets for physical activity, but some evidence suggests these resources are not equitably distributed.

Purpose: This study examined disparities by income and race/ethnicity in the availability, features, and quality of parks across Kansas City, Missouri.

Methods: All parks and census tracts (CTs) were mapped using GIS and park features and quality were determined via audits. MANCOVAs analyzed differences in park availability, features, and quality across low, medium and high income and race/ethnicity CT tertiles.

Results: Low income CTs contained significantly more parks, but also had fewer parks with playgrounds and more quality concerns per park. High minority CTs had more parks with basketball courts, but fewer parks with trails. Medium income CTs contained more aesthetic features per park.

Conclusions: Future research should examine policies that contribute to and that might rectify disparities in park features and quality, especially in low income and high minority areas.
\end{abstract}

Keywords: parks, built environment, physical activity, income, race/ethnicity, environmental justice 
Recent physical activity (PA) promotion and obesity prevention efforts have adopted social ecological models that emphasize the role of the built environment in facilitating or constraining opportunities for active transportation and recreation $(1,2)$. Public parks are a major environmental resource in most communities and their proximity, accessibility, design, and quality are all important factors influencing their usage and impact on population-level PA (3-9). Indeed, public parks generally offer diverse opportunities for PA, are present in most communities at low or no cost, and can thereby reach a large proportion of the population, especially disadvantaged groups who may not have access to other resources (10).

The idea of environmental justice (EJ) provides a conceptual foundation for investigating built environment disparities in low income and racially/ethnically diverse communities that may be influencing poorer rates of physical activity and health (11). Several authors (12-14) have previously provided excellent theoretical and historical overviews of the relevance of EJ to research on parks and outdoor recreation, as well as alternative conceptualizations and definitions of various ideas related to EJ (e.g., distributive and procedural justice, environmental equity, environmental racism). According to one prominent review paper citing the U.S. Environmental Protection Agency, EJ can be defined as the fair treatment and meaningful involvement of all people in the development, implementation, and enforcement of laws, regulations, and policies about diverse environmental issues (15). Although proponents justifiably advocate for greater involvement of affected citizens in actions to promote EJ, more attention in the research literature thus far has addressed the fair treatment component (16). Indeed, a growing body of research has examined whether various PA resources 
are equitably distributed by neighborhood socioeconomic status (SES) or ethnic/racial composition. Within this literature, it has often been concluded that areas with lower SES and/or a higher minority population contain significantly fewer parks and recreational resources than their higher SES and low minority counterparts (17-22). However, other studies have reported that park availability is equal or greater in lowincome and/or high minority neighborhoods (23-26), so further research is warranted. Moreover, another recent study in Los Angeles (14) reported that there were more, but often smaller, parks in low income and minority neighborhoods, thus leading to more park pressure or congestion (i.e., less park space per capita). Additionally, little research has explored disparities in the specific facilities and amenities within parks. One exception in Australia found that within higher SES neighborhoods, public open spaces were more abundant and possessed more total amenities (e.g., picnic tables, drinking fountains, toilets) and were more likely to have shade trees, water features, walking and cycling paths, lighting, and various types of signage (27). Finally, few studies $(28,29)$ have evaluated the actual quality of parks and recreation resources by neighborhood composition. However, researchers in New Zealand (30) found that public open spaces in less deprived areas had higher environmental quality scores (e.g., trees, water features, lack of graffiti and litter) than those in more deprived areas.

In summary, parks are important physical activity resources, especially for promoting PA and health-related EJ in low income and minority communities. Therefore, the purpose of this study was to examine disparities in park availability, features, and overall park quality across socioeconomically and racially/ethnically diverse census tracts in Kansas City, Missouri. We hypothesized that park availability would not differ 
by census tract income or race/ethnicity composition, but that there would be fewer park features and lower overall park quality in parks in tracts with lower household incomes and a greater percentage of minority residents.

$$
\text { Methods }
$$

\section{Study Area and Sample}

This study was set in Kansas City, Missouri (KCMO), which intersects four counties, covers 313 square miles, and is home to almost one-half million $(441,545)$ residents. The KCMO population is ethnically and racially diverse (White $=61 \%$, Black $=31 \%$, Hispanic $=7 \%$ ) and has a broad income distribution (median household income $=\$ 39,230 ; 14 \%$ at or below the poverty line) (31). At the time of the study, there were 219 parks and approximately 12,000 acres of total parkland in KCMO. Parks were identified for enumeration and location in the present study using Geographical Information Systems (GIS) shape files provided by the KCMO Parks and Recreation Department. All parks in the original GIS file were visited and audited to determine if they were publicly accessible and useable for recreation. Parks that did not meet this criterion (e.g., deep ravines, grounds of public buildings) were not included in the study because the emphasis was on disparities in access to sites for PA and recreation. Ultimately, 165 parks were included in an edited GIS file and this edited file was crossreferenced by location with census tracts to allocate parks (and their area and characteristics) to tracts (as described further below).

The units of analysis for this study were census tracts in KCMO. Census tracts are small, generally permanent subdivisions of a county that usually contain from 2,500 8,000 people and are fairly homogenous in terms of population characteristics, 
economic status, and living conditions (32). In ArcGIS, shape files representing the $\mathrm{KCMO}$ municipal boundary and all tracts in the four counties were overlaid to determine tracts partially or fully within $\mathrm{KCMO}$. In total, 186 tracts intersected $\mathrm{KCMO}$, but 12 were more than $50 \%$ outside the city boundary and were therefore excluded to maintain the focus on KCMO residents and parks. Most of the excluded tracts simply shared an edge with the $\mathrm{KCMO}$ boundary and therefore, only one small City of $\mathrm{KCMO}$ park was found within these excluded tracts. In the end, a final sample of 174 tracts was analyzed.

\section{Measures}

Census Tract Income and Race/Ethnicity

The American Community Survey (ACS) was used to gather information on race/ethnicity and income for each census tract (33). ACS 5-year (2005-2009) estimates are available at the census tract level and were downloaded. The median household income for each census tract was used to categorize tracts into three even tertiles (low, medium, and high income). For race/ethnicity, we identified the percentage of minority residents, defined as non-White and Hispanic White persons, and tracts were again categorized into even tertiles (low, medium, and high percent minority). For both income and percent minority, tracts were grouped into categories in order to ease interpretation between high versus medium versus low income or percent minority areas and to maintain consistency with most past studies exploring similar issues $(17,19,20,22-27)$. Park Availability

Our first dependent variable was park availability, which was measured in two ways. First, we used ArcGIS to determine the number of parks whose boundaries 
intersected the boundary of each census tract (23). Second, a total amount of park space (acres) was calculated by summing the area of all parks that intersected the tract. Park Features

The features and quality of all parks in the study were assessed using the Community Park Audit Tool (CPAT; 34). Audits of all KCMO parks were conducted by both trained community stakeholders and research assistants who underwent both classroom training on the CPAT and practice field audits in parks not included in the present study. The duration of the audits ranged from 10 to 65 minutes (mean=32 min) and all data were collected in Fall 2010 and Spring 2011. Inter-rater reliability tests were conducted on data collected by two independent auditors in 66 diverse parks used in the present study. The CPAT was found to possess excellent inter-rater reliability, with all but eight items demonstrating at least moderate to perfect agreement and only 3 items with percent agreement less than $70 \%$ (34).

In this study, similar to past research (9), we divided the park features rated within the CPAT into 'facilities' and 'amenities'. Facilities were areas in the park that could be used for PA while amenities were park features that might support PA. Park facilities included 14 park activity areas - baseball fields, basketball courts, dog parks, fitness stations, green spaces, lakes, playgrounds, skate parks, splash pads, sports fields, swimming pools, tennis courts, trails, and volleyball courts. Park amenities included 25 total features that were divided into 7 neighborhood amenities (transit stop, car parking, sidewalk, external trail, traffic signal, bike lane, bike rack), 11 quality amenities (restroom, drinking fountain, benches, picnic table, picnic shelter, grill, vending machine, trash can, shade, rules posted about animals, animal waste bags), 
and 7 safety amenities (lights, park monitored, dangerous spots, threatening behaviors, neighborhood visibility, roads through the park, emergency device; note that two of these park amenities - dangerous spots and threatening behaviors - may not fit the traditional definition of a positive park attribute that contributes to park visitors' PA, but they have been included amongst the other non-facility park features while recognizing this inconsistency).

In this study, we first calculated the average number of total park facilities, total positive park amenities, and total park features (facilities plus positive amenities) per park for each census tract. Like other studies, we then examined disparities in each facility or amenity individually $(26,27)$. Specifically, we calculated the proportion of parks in each tract that contained each type of facility or amenity (e.g., 2 of 5 parks $=0.40$ ) Park Quality

Finally, to assess park quality, the presence of both overall park quality concerns - or what are sometimes referred to as incivilities (26) - as well as positive aesthetic features in the parks were also audited using the CPAT tool. Quality concerns were measured using an index of 6 negative attributes (e.g., vandalism, graffiti, excessive litter) and aesthetic features were measured with a list of 7 items that might enhance park attractiveness or enjoyment (e.g., artistic feature, historical/educational feature, water feature, etc.). The total number of quality concerns and the total number of aesthetic features were summed for each park to determine the mean number of quality concerns and the mean number of aesthetic features per park for each tract (29). Analyses 
Multivariate analyses of covariance (MANCOVAs) were used to compare low, medium, and high census tracts (for each of income and percent minority) with respect to i) the number of parks and the total amount of park space, ii) the average number of total park features, facilities, and amenities per park, iii) the proportion of parks with individual facilities and amenities, and iv) the average number of park quality concerns and aesthetic features per park. Significant omnibus MANCOVAs were followed by univariate ANCOVAs for each dependent variable and Sidak post-hoc tests of between group differences. All analyses controlled for the land area of the tract, total tract population, percentage of the tract population under 18 years old, and the tract's income or percent minority (when not used to stratify the sample of tracts to begin with).

\section{Results}

Table 1 shows the descriptive characteristics of the 174 tracts included in the study. The average median household income of all tracts was $\$ 42,747(\mathrm{SD}=\$ 23,951)$ and the mean percent minority for all tracts was $50.4 \%$ (SD=33.2\%). Across all census tracts, there was an average of 1.22 parks per tract $(S D=1.14$, range $=0-6), 152.2$ park acres per tract $(S D=410.9$, range $=0-1853), 3.87$ out of 14 facilities per park $(S D=2.07$, range $=0-11), 8.75$ out of 23 positive amenities per park $(S D=3.13$, range=2-17), 12.6 out of 37 total features per park ( $S D=4$., range=3-27), 0.57 quality concerns per park $(S D=0.71$, range $=0-4)$, and 2.47 aesthetic features per park $(S D=1.45$, range $=0-6)$.

\section{Park Availability}

Table 2 shows the relationship between tract income and percent minority and the number of parks and total park acres per census tract. The overall MANCOVA comparing both the number of parks and total park acres across income tertiles was 
statistically significant $(F=4.76, p<.01)$. When examined individually, the number of parks was significantly different across low, medium, and high income tracts $(F=6.28$, $\mathrm{p}<.01)$. Specifically, low income tracts $(M=1.46, S D=1.25)$ had significantly more parks than medium $(M=1.25, S D=1.00)$ or high $(M=1.00, S D=1.10)$ income tracts. As well, the post-hoc test comparing medium and high income tracts approached significance $(p=.06)$. These patterns are illustrated in Figure 1 which depicts the number of parks across all low, medium, and high income census tracts.

For total park acres across income tertiles, the ANCOVA test approached significance $(F=3.09, p=.05)$, but post-hoc tests revealed no differences between the three groups. Finally, the overall MANCOVA comparing both the number of parks and total park acres across percent minority tertiles was not significant $(F=0.77, p=0.54)$. As shown in the bottom half of Table 2, when examining the low, medium, and high percent minority groups, no differences were found for the number of parks $(F=0.08, p=0.92)$ or total park acres per census tract $(F=1.52, p=0.22)$.

Park Features

The overall MANCOVA comparing the average total number of facilities, amenities, and total features per park across income tertiles was not significant $(F=0.56$, $p=0.70)$. Likewise, there also were no significant differences among percent minority groups for the average total number of facilities, amenities, or total features $(F=0.37$, $\mathrm{p}=0.83$ ). However, as discussed below, several individual park facilities and amenities differed across tract income and race/ethnicity tertiles.

Table 3 illustrates the proportion of parks with individual park facilities. Only eight of the 14 facilities were included in the analysis because some facilities were either too 
prevalent (e.g., green spaces) or too scarce (e.g., splash pads) within parks that variation across tertiles was non-existent (the specific inclusion criteria was a skewness value for the facility variable from -3 to +3$)$. The overall MANCOVA comparing the proportion of parks with individual facilities per census tract by income approached statistical significance $(\mathrm{F}=1.66, \mathrm{p}=0.06)$. As shown in Table 3 , the proportion of parks with playgrounds differed significantly across income groups $(F=4.88, p<.01)$, with low $(M=0.62, S D=0.40)$ and medium $(M=0.52, S D=0.41)$ income tracts having a lower proportion of parks with playgrounds than high income tracts $(M=0.69, S D=0.38)$. Additionally, the overall MANCOVA comparing the proportion of parks with individual facilities across percent minority tertiles was significant $(F=2.60, p<.01)$. Specifically, the proportion of parks with basketball courts was greater in high minority $(M=0.59$, $\mathrm{SD}=0.43)$ tracts than in medium $(\mathrm{M}=0.30, \mathrm{SD}=0.40)$ or low $(\mathrm{M}=0.13, \mathrm{SD}=0.29)$ minority tracts $(F=5.18, p<.01)$. As well, the proportion of parks with trails was greater in low $(M=0.60, S D=0.41)$ and medium $(M=0.55, S D=0.41)$ minority tracts than high minority $(\mathrm{M}=0.39, \mathrm{SD}=0.41)$ tracts $(\mathrm{F}=5.61, \mathrm{p}<.01)$.

Tables 4-6 show the proportion of parks in each tract with various individual amenities (similar to the park facilities analyses, 4 amenities - bike parking, bike lanes, vending machines, and emergency devices - were excluded from the analysis due to low variation). To account for conceptual differences between the types of assessed amenities, we split the remaining 21 amenities into three distinct groups for the MANCOVA analyses: neighborhood amenities (Table 4), quality amenities (Table 5), and safety amenities (Table 6). 
The overall MANCOVA comparing the proportion of parks with various neighborhood amenities by income tertiles approached significance $(F=0.85, p=0.05)$. When examined individually, as shown in Table 4, the proportion of parks with sidewalks was significantly higher in low $(M=0.87, S D=0.28)$ and high income $(M=0.74$, $\mathrm{SD}=0.38)$ tracts than in medium income $(\mathrm{M}=0.61, \mathrm{SD}=0.43)$ tracts $(F=5.13, \mathrm{p}=.01)$. The overall MANCOVA comparing the proportions of parks with neighborhood amenities by percent minority was not significant $(F=1.10, p=0.36)$.

Table 5 shows the proportion of parks with various quality amenities by tract income and percent minority. The overall MANCOVA comparing the park quality amenities by tract income group was not significant $(F=0.51, p=0.96)$. Further, the overall MANCOVA comparing the park quality amenities by tract percent minority group approached significance $(F=1.59, p=0.05)$. The univariate ANCOVA comparing the proportion of parks with restrooms across high, medium, and low percent minority census tracts also approached statistical significance $(F=2.45, p=0.09)$, with low $(M=0.34, S D=0.40)$ and medium $(M=0.27, S D=0.33)$ percent minority tracts being somewhat more likely to have parks with restrooms than high $(M=0.20, S D=0.35)$ minority tracts (Table 5).

Finally, the overall MANCOVAs comparing the proportion of parks with safety amenities were not significant for income $(F=0.78, p=0.67)$ or percent minority $(F=0.97$, $p=0.48$ ). Table 6 shows the analyses for the six park safety amenities, none of which differed significantly across income or percent minority tertiles.

Park Quality 
Table 7 shows the average number of quality concerns (i.e., incivilities) and aesthetic features per park by income and percent minority tertiles. The overall MANCOVA simultaneously comparing quality concerns and aesthetic features per park across income tertiles was significant $(F=4.84, p<.01)$. The number of quality concerns per park varied across income groups $(F=3.74, p=0.03)$, with more quality concerns per park in low income tracts $(M=0.75, S D=0.89)$ than in high $(M=0.42, S D=0.57)$ or medium $(M=0.50, S D=0.56)$ income tracts. The average number of aesthetic features per park across the three income categories was also significantly different $(F=6.08$, $p<.01)$, with more aesthetic features per park in medium income tracts $(M=3.02$, $S D=1.57)$ than in high income tracts $(M=2.29, S D=1.31)$. Finally, the MANCOVA comparing quality concerns and aesthetic features per park by census tract percent minority group was not significant $(F=1.02, p=0.40)$.

\section{Discussion}

\section{Park Availability}

In $\mathrm{KCMO}$, overall park availability was greater in low income areas. The present findings are similar to a study in California which found that there were more places to engage in PA in low SES areas (25). Other researchers have reported no discrepancies in park availability between areas of differing SES $(24,35,36)$, but there is an equally substantial body of evidence documenting fewer parks in lower income areas (17-22). In $\mathrm{KCMO}$, our findings might be explained by the fact that low income and diverse populations are generally found within the older, urban core of the city (Figure 1). Many core areas of cities in the U.S. were developed at a time (i.e., prior to mass automobile use) when integrated planning and mixed use development were more common; these 
development patterns often included abundant numbers of parks and green spaces in concert with residential, commercial, and industrial land uses $(37,38)$. The urban cores of many large cities have since been gentrified toward higher income businesses and households, but in those cities where this has not occurred, park availability may yet be skewed toward more central, lower income tracts.

\section{Park Features}

While park availability is important, park facilities and amenities may be equally significant determinants of park use and PA (9). In the present study, the average total number of facilities, amenities, and features per park was not significantly different across income or percent minority tertiles. These findings are similar to another study conducted in $\mathrm{KCMO}$ (39). However, these totals may mask inequities in the distribution of specific types of park features across neighborhoods throughout the city. Indeed, in our study, high income tracts had more playgrounds per park than low or medium income tracts. Another study in Australia found similar results in that there were fewer playgrounds and other facilities and amenities (i.e., bike paths, picnic tables) conducive to children's PA in lower SES areas (27). These findings are problematic because playgrounds have been shown to promote increased PA intensity and healthier weight status among children (40-42). Areas of low SES are perhaps the neighborhoods that need playgrounds the most due to the increased likelihood of those areas having a higher prevalence of youth who are overweight or obese (43).

The proportion of parks with basketball court facilities was significantly greater in high minority census tracts. Conversely, the proportion of parks with trails was lower in high minority tracts. Another study reported that lower SES areas contained fewer trails 
(44). Overall, these findings are disconcerting as trails are key park resources for PA $(9,45)$. Likewise, several studies have reported that basketball courts are potential places to intervene due to their high levels of use and user energy expenditure $(41,46)$. The greater number of basketball courts in high minority areas could be a product of greater demand for these facilities at the time certain parks were built. However, for all of the disparities observed, future research should explore why certain key park facilities are more prevalent in different areas and the impact this has on park use and PA participation. Nevertheless, none of the other park facilities in our analyses approached significance, which is promising from an EJ standpoint in that there is a relatively equal distribution for most facilities across tracts in KCMO.

The one individual amenity that was significant in the analyses was sidewalks, with there being a higher proportion of parks with sidewalks in low and high income compared to medium income tracts. Sidewalks are an important predictor of PA and the absence of such amenities around parks should not be ignored (47). As well, a study conducted in St. Louis, MO found that neighborhoods that were predominantly African American were much more likely to have uneven sidewalks and sidewalks with obstructions than predominantly White neighborhoods (48). Therefore, future research should examine not only sidewalk availability, but also the condition of such accessrelated amenities around parks.

Park Quality

Finally, there were a greater number of overall park quality concerns (i.e., incivilities) per park in low income tracts and more aesthetic features per park in medium income tracts. Few previous studies have assessed park quality concerns, but 
these findings are consistent with researchers in Canada who found that playgrounds in high need areas were more likely to be below standard quality (32). Related to this, Coen and Ross (49) reported there were more quality concerns in parks in areas of poor health status. With respect to aesthetic features, researchers in Melbourne found that there were more aesthetic features (i.e., picnic tables, water features, lighting) in higher SES areas (27), and that the quality of neighborhood resources is a predictor of engaging in more outdoor activities (50). Thus, more quality concerns and fewer aesthetic features within parks can lead to both poorer perceptions and actual problems related to park attractiveness and safety, which can deter park visitation and use. Consequently, EJ efforts must take into account not only the availability of parks and the features therein, but also the quality of those resources and their attractiveness for PA. Limitations

The present study had several limitations. We examined the number of parks and park acreage that interested the census tract, whereas future research may wish to employ other measures of park availability and accessibility. For example, Sister et al. (2010) defined service areas around parks and calculated a measure of "potential park congestion (or pressure)" based on the ratio of persons within the service area relative to the size of the park (14). They found that Latinos, African-Americans, and low income groups were more likely to live close to parks with higher potential park congestion. Others have used such diverse measures as acres of park space per 1,000 population (e.g., all residents, those under 18 years, those over 65 years, households without automobiles, etc.), percentage of open space relative to all available land, size of the largest park, or park and recreation funding per capita $(12,23,51,52)$. 
Another limitation was that, given our detailed emphasis on public park availability, features, and quality, resources such as private parks, school grounds, and other recreation facilities were not examined. Further, not all of the park facilities and amenities audited could be included in the analyses due to a lack of variability for some (too scarce or too common). As well, the present study only accounted for quality concerns and aesthetic features of the overall park, not the quality of individual facilities and amenities (again due to low variability in facility and amenity condition ratings). Additionally, we did not have information on the age of the parks and future research (using park maps and audits over time) may wish to track whether the associations we observed are becoming stronger or being diluted.

A final limitation was that our study considered only one half of the EJ equation. Although we, like others, examined relatively thoroughly the fair treatment aspect of park provision, further efforts should be made to ensure meaningful involvement by citizens in actions that might uncover and rectify any disparities in park availability, features, or quality across communities. Parks are encouraging sites for promoting PA because their provision and management can be influenced through public policy $(10,53)$, but all groups do not always have equal access to policy making processes (54). Unlike many other park audit tools, the CPAT was designed with and for nonresearchers as a user-friendly yet reliable instrument that could be incorporated into community evaluation and advocacy efforts (34). In addition to producing and testing the tool, the diverse community stakeholders involved in its development reported a range of positive process-related outcomes (e.g., increased resource awareness; networking and community-building) from their engagement in the project (34). 
Likewise, another study in two low income urban neighborhoods reported that another park audit tool - the Physical Activity Resource Assessment (29) - was a useful needs assessment and program planning tool that facilitated familiarity with the local built and social environments (55). Further, Ghaemi et al. (56) reported on the development of a web-based tool that would permit community organizations to analyze population demographics and green space distribution and identify areas where parks are needed. Ongoing efforts such as these should continue to engage diverse constituencies in environmental change initiatives, especially youth who may be the next wave of advocates for healthy community design (57).

Important follow-up research could also include policy analysis or historical analysis to uncover mechanisms that have led to observed disparities in KCMO and elsewhere. For example, Boone et al. (12) used official park plans, municipal master plans and ordinances, newspaper accounts, unpublished documents from neighborhood associations, and records from government mortgage and housing agencies to document historical patterns and events related to racial segregation and residential migration that have shaped park access for low income and minority groups in Baltimore, MD. In general, concerns about the fair treatment element of EJ should be balanced with increased respect for the meaningful involvement of citizens in producing such outcomes and for an understanding of forces that influence park availability and distribution.

\section{Conclusion}

Our study uncovered few wide discrepancies in park availability, features, or quality across tracts, but there were subtle marked differences that should not be 
overlooked. Low income and racially/ethnically diverse areas of KCMO are generally found within the older, urban core of the city where the inclusion of parks in neighborhood planning appears to have been more common. However, similar to past research showing less spending per capita in at-risk neighborhoods (22), greater investments in certain park facilities and amenities in these neighborhoods may also be necessary. Future research and practice should investigate law and policy changes that can ameliorate environmental disparities in the areas where quality parks are needed most. Moreover, more research is needed to examine how disparities in access to quality park environments are associated with PA and health outcomes. Addressing such disparities in low income and high minority areas will help in leveling the playing field to combat the obesity crisis through the provision of equitable environmental supports for PA.

\section{Acknowledgments}

This study was supported by funding from the Health Care Foundation of Greater Kansas City, as well as Active Living Research, a national program of the Robert Wood Johnson Foundation. We wish to acknowledge the assistance of three knowledgeable reviewers who provided valuable feedback on an earlier draft of this paper. 


\section{References}

1. Sallis JF, Cervero R, Ascher WW, Henderson K. Kraft, MK, Kerr J. An ecological approach to creating active living communities. Annu Rev Public Health. 2006; 27: 1-26.

2. Sallis JF, Owen N, Fisher EB. Ecological models of health behavior. In: Glanz K, Rimer B, Viswanath K, eds. Health behavior and health education: theory, research, and practice. 4th ed. San Francisco, CA: Jossey-Bass; 2008:465-482.

3. Bedimo-Rung AL, Mowen AJ, Cohen DA. The significance of parks to physical activity and public health: A conceptual model. Am J Prev Med. 2005; 28: 159168.

4. Kaczynski AT Henderson K A. Environmental correlates of physical activity: A review of evidence about parks and recreation. Leisure Sciences. 2007; 29: 315354.

5. Giles-Corti B, Broomhall MH, Knuiman M, Collins C, Douglas K, Ng K, Lange A, Donovan RJ. Increasing walking: How important is distance to, attractiveness, and size of public open space. Am J Prev Med. 2005; 28: 169-176.

6. Cohen DA, McKenzie TL, Sehgal A, Williamson S, Golinelli D, Lurie N. Contribution of public parks to physical activity. Am J Public Health. 2007; 97(3): 509-514.

7. Kaczynski AT, Potwarka LR, Smale BJ, Havitz ME. Association of parkland proximity with neighborhood and park-based physical activity: Variations by gender and age. Leisure Sci. 2009; 31: 174-191.

8. Sugiyama T, Francis J, Middleton NJ, Owen N, Giles-Corti B. Associations between recreational walking and attractiveness, size, and proximity of neighborhood open spaces. Am J Public Health. 2010;100(9):1752-1757.

9. Kaczynski AT, Potwarka LR, Saelens BE. Association of park size, distance, and features with physical activity in neighborhood parks. Am J Public Health. 2008; 98: 1451-1456.

10. Godbey GC, Caldwell LL, Floyd M, Payne LL. Contributions of leisure studies and recreation and park management research to the active living agenda. Am J Prev Med. 2005; 28: 150-158.

11. Floyd MF, Taylor WC, Whitt-Glover M. Measurement of park and recreation environments that support physical activity in low-income communities of color: Highlights of challenges and recommendations. Am J Prev Med. 2009; 36: S156-S160.

12. Boone CG, Buckley GL, Grove JM, Sister C. Parks and people: An environmental justice inquiry in Baltimore, Maryland. Annals of the Association of American Geographers. 2009; 99:4, 767-787.

13. Floyd MF, Johnson CY. Coming to terms with environmental justice in outdoor recreation: A conceptual discussion with research implications. Leisure Sciences. 2002; 24:59-77.

14. Sister C, Wolch J, Wilson J. Got green? Addressing environmental justice in park provision. GeoJournal. 2010; 75: 229-248. 
15. Taylor WC, Poston WSC, Jones L, Kraft K. Environmental justice: Obesity, physical activity, and healthy eating. J Phys Act Health. 2005; 3: S30-S54.

16. Taylor WC, Lou D. Do all children have places to be active? Disparities in access to physical activity environments in racial and ethnic minority and lower-income communities. Active Living Research: Research Synthesis. November 2011.

17. Moore LV, Diez-Roux AV, Evenson KR, McGinn AP, Brines SJ. Availability of recreational resources in minority and low socioeconomic status areas. Am J Prev Med. 2008; 34: 16-22.

18. Powell LM, Slater S, Chaloupka FJ, Harper D. Availability of physical activityrelated facilities and neighborhood demographic and socioeconomic characteristics: A national study. Am J Public Health. 2006; 96: 1676-1680.

19. Estabrooks PA, Lee RE, Gyurcsik NC. Resources for physical activity participation: Does availability and accessibility differ by neighborhood socioeconomic status? Ann Behav Med. 2003; 25: 100-104.

20. Gordon-Larsen P, Nelson MC, Page P, Popkin BM. Inequality in the built environment underlies key health disparities in physical activity and obesity. Pediatrics. 2006; 117: 417-424.

21. Talen $\mathrm{E}$. The social equity of urban service distribution: An exploration of park access in Pueblo, Colorado and Macon, Georgia. Urban Geography. 1997; 18: 521-541.

22. Wolch J, Wilson JP, Fehrenbach J. Parks and park funding in Los Angeles: An equity-mapping analysis. Urban Geography. 2005; 26: 4-35.

23. Abercrombie LC, Sallis JF, Conway TL, Frank LD, Saelens BE, Chapman JE. Income and racial disparities in access to public parks and private recreation facilities. Am J Prev Med. 2008; 34: 9-15.

24. Gilliland J, Holmes M, Irwin J, Tucker P. Environmental equity is child's play: Mapping public provision of recreation opportunities in urban neighborhoods. Vulnerable Children and Youth Studies. 2006; 1: 256-268.

25. Lee RE, Cubbin C, Winkleby M. Contribution of neighborhood socioeconomic status and physical activity resources to physical activity among women. J Epidemiol Community Health. 2007; 61: 882-890.

26. Macintyre S, Macdonald L, Ellaway A. Do poorer people have poorer access to local resources and facilities? The distribution of local resources by area deprivation in Glasgow, Scotland. Soc Sci Med. 2008; 67: 900-914.

27. Crawford D, Timperio A, Giles-Corti B, et al. Do features of public open spaces vary according to neighborhood socio-economic status? Health Place. 2008; 14: 889-893.

28. Smoyer-Tomic KE, Hewko JN, Hodgson MJ. Spatial accessibility and equity of playgrounds in Edmonton, Canada. The Canadian Geographer. 2004; 48: 287302.

29. Lee RE, Booth KM, Reese-Smith JY, Regan G, Howard HH. The Physical Activity Resource Assessment (PARA) instrument: Evaluating features, amenities and incivilities of physical activity resources in urban neighborhoods. International Journal of Behavioral Nutrition and Physical Activity. 2005; 2: 1-9. 
30. Badland HM, Keam R, Witten K, Kearns R. Examining public open spaces by neighborhood-level walkability and deprivation. J Phys Act Health. 2010; 7(6): 818-824.

31. United States Census Bureau. State \& County QuickFacts: Kansas City, Missouri. United States Census Bureau. Accessed at: http://quickfacts.census.gov/qfd/states/29/2938000.html on May 11, 2011.

32. United States Census Bureau. Census tracts and block numbering areas. United States Census Bureau, Geography Division. Accessed May 1, 2011 at: http://www.census.gov/geo/www/cen_tract.html

33. American Community Survey (2011). About the American Community Survey. Accessed May 1, 2011 at: http://www.census.gov/acs/www/about_the_survey/ american_community_surveyl

34. Kaczynski AT, Wilhelm Stanis SA, Besenyi GM. Development and testing of a community stakeholder park audit tool. Am J Prev Med. 2012; 42(3): 242-249.

35. Nicholls S. Measuring the accessibility and equity of public parks: A case study using GIS. Managing Leisure. 2001; 6: 201-219.

36. Timperio A, Giles-Corti B, Crawford D, et al. Features of public open spaces and physical activity among children: Findings from the CLAN study. Prev Med. 2008; 47: 514-518.

37. Jacobs J. The death and life of great American cities. New York: Random House. 1961.

38. Southworth M. Designing the walkable city. Journal of Urban Planning and Development. 2005; 131: 246-257.

39. Suminksi RR, Ding D, Lee R, May L, Tota T, Dinius D. Youth physical activity opportunities in lower and higher income neighborhoods. J Urban Health. 2011; 88: 599-615.

40. Besenyi GB, Wilhelm Stanis SA, Kaczynski AT. Observed physical activity by park setting among youth by gender, age, and race/ethnicity. Presented at the Active Living Research Eighth Annual Conference, February 22-24, 2011, San Diego, CA.

41. Floyd MF, Spengler JO, Maddock JE, Gobster PH, Suau LJ. Park-based physical activity in diverse communities of two United States cities. Am J Prev Med. 2008; 34: 299-305.

42. Potwarka LR, Kaczynski AT, Flack AL. Places to play: Association of park space and facilities with healthy weight status among children. J Community Health. 2008; 33: 344-350.

43. Grow HMG. Childhood obesity associated with social disadvantage of children's neighborhoods. Social Science and Medicine. 2010; 71: 584-591.

44. Wilson DK, Kirtland KA, Ainsworth B, Addy CL. Socioeconomic status and perceptions of access and safety for physical activity. Ann Behav Med. 2004; 28 : 20-28.

45. Paxton RJ, Sharpe PA, Granner ML, Hutto B. Associations of sociodemographic and community environmental variables to use of public parks and trails for physical activity. International Journal of Health Promotion \& Education. 2005; 43: 108-116. 
46. Rung AL, Mowen AJ, Broyles ST, Gustat J. The role of park conditions and features on park visitation and physical activity. J Phys Act Health. 2011; 8: S178-S187.

47. Christensen KM, Holt JM, Wilson JF. Effects of perceived neighborhood characteristics and use of community facilities on physical activity of adults with and without disabilities. Prev Chronic Dis. 2010; 7: A105.

48. Kelly CM, Schootman M, Baker EA, Barnidge EK, Lemes A. Evidence-based public health policy and practice: The association of sidewalk walkability and physical disorder with area-level race and poverty. J Epidemiol Community Health. 2007; 61: 978-983.

49. Coen SE, Ross NA. Exploring the material basis for health: Characteristics of parks in Montreal neighborhoods with contrasting health outcomes. Health Place. 2006; 12: 361-371.

50. Veitch J, Timperio A, Crawford D, Abbott G, Giles-Corti B, Salmon J. Is the neighborhood environment associated with sedentary behavior outside of school hours among children? Ann Behav Med. 2011; 41: 333-341.

51. Timperio A, Ball K, Salmon J, Roberts R, Crawford D. Is availability of public open space equitable across areas? Health \& Place. 2007; 13: 335-340.

52. Jossart-Marcelli P. Leveling the playing field? Urban disparities in funding for local parks and recreation in the Los Angeles region. Environment and Planning. 2010; 42: 1174-1192.

53. Moody JS, Prochaska JJ, Sallis JF, McKenzie TL, Brown M, Conway TL. Viability of parks and recreation centers as sites for youth physical activity. Health Promot Pract. 2004; 5:4, 438-443.

54. Freudenberg N, Pastor M, Israel B. Strengthening community capacity to participate in making decisions to reduce disproportionate environmental exposures. Am J Public Health. 2011: 101, S1:S123-S130.

55 . DeBate RD, Koby EJ, Looney TE, et al. Utility of the physical activity resource assessment for child-centric physical activity intervention planning in two urban neighborhoods. J Community Health. 2011; 36(1): 132-140.

56. Ghaemi P, Swift J, Sister C, Wilson JP, Wolch J. Design and implementation of a web-based platform to support interactive environmental planning. Computers, Environment and Urban Systems. 2009; 33:6, 482-491.

57. Millstein RA, Sallis JF. Youth advocacy for obesity prevention: The next wave of social change for health. Translational Behavioral Medicine. 2011; 1: 497-505. 
Table 1

Tract Characteristics

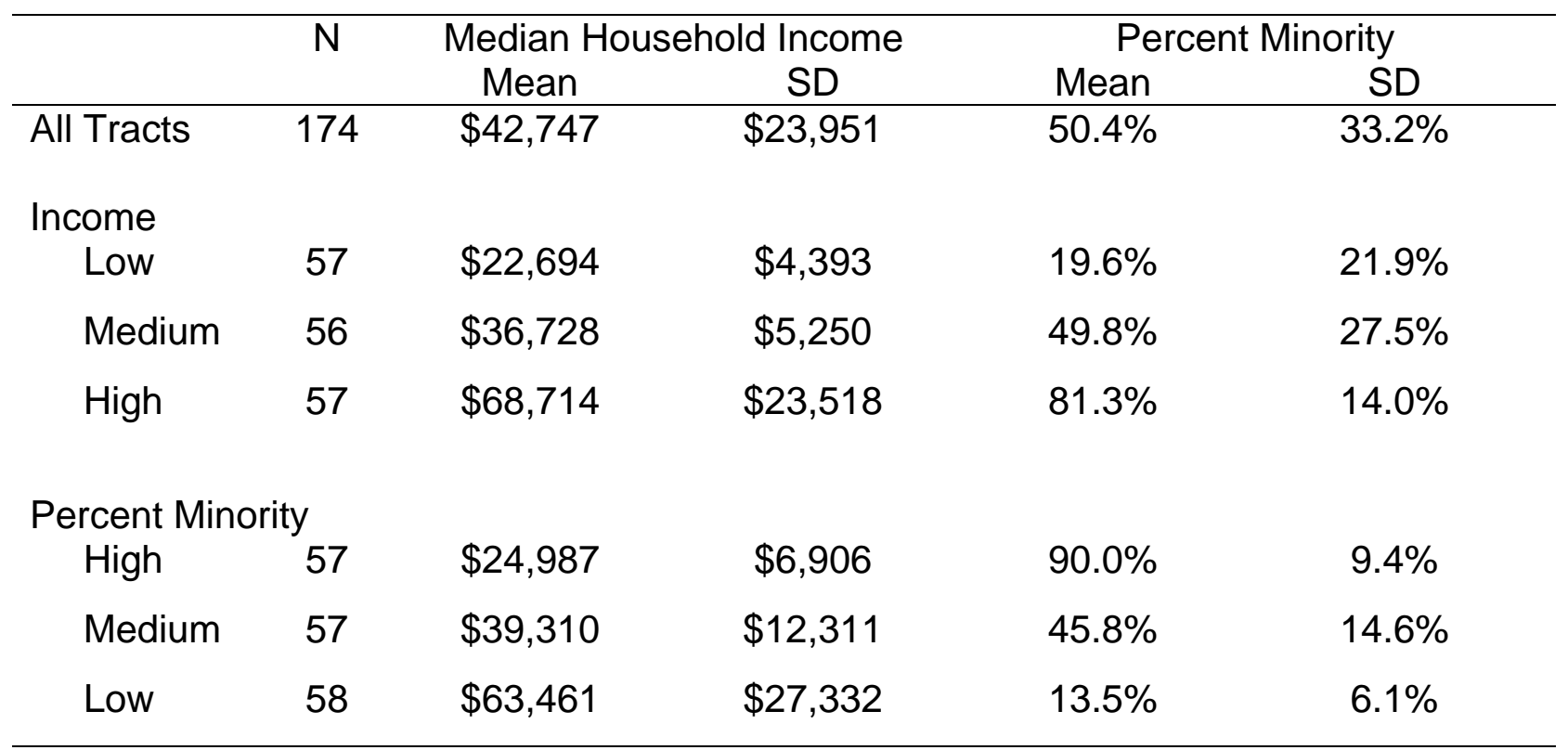

Note: 4 tracts were missing income data and 2 tracts were missing race/ethnicity data. 
Table 2

Differences in Park Availability by Income and Percent Minority

\begin{tabular}{|c|c|c|c|c|c|}
\hline \multirow{2}{*}{$\begin{array}{l}\text { Census Tract } \\
\text { Characteristic }\end{array}$} & \multirow{2}{*}{$\mathrm{N}$} & \multicolumn{2}{|c|}{ Number of Parks } & \multicolumn{2}{|c|}{ Total Park Acres } \\
\hline & & Mean & SD & Mean & SD \\
\hline \multicolumn{6}{|l|}{ Income $^{1}$} \\
\hline Low & 57 & $1.46^{a}$ & 1.25 & 154.30 & 420.75 \\
\hline Medium & 56 & $1.25^{\mathrm{b}}$ & 1.00 & 246.82 & 544.54 \\
\hline High & 57 & $1.00^{\mathrm{b}}$ & 1.10 & 66.93 & 188.41 \\
\hline $\mathrm{F}$ & & \multirow{2}{*}{\multicolumn{2}{|c|}{$\begin{array}{c}6.28 \\
2.163\end{array}$}} & \multicolumn{2}{|c|}{3.09} \\
\hline df & & & & & \\
\hline $\mathrm{p}$ & & \multicolumn{2}{|c|}{$<.01$} & \multicolumn{2}{|c|}{0.05} \\
\hline \multicolumn{6}{|l|}{ Percent Minority ${ }^{2}$} \\
\hline High & 57 & 1.28 & 1.05 & 194.48 & 506.82 \\
\hline Medium & 55 & 1.27 & 1.13 & 200.72 & 475.10 \\
\hline Low & 58 & 1.16 & 1.23 & 74.27 & 185.88 \\
\hline $\mathrm{F}$ & & \multicolumn{2}{|c|}{0.08} & \multicolumn{2}{|c|}{1.52} \\
\hline$d f$ & & \multicolumn{2}{|c|}{2,163} & \multirow{2}{*}{\multicolumn{2}{|c|}{2,163}} \\
\hline $\mathrm{p}$ & & \multicolumn{2}{|c|}{0.92} & & \\
\hline
\end{tabular}

${ }^{1}$ MANCOVA: $F=4.76, d f=4,324, p<.01$

${ }^{2}$ MANCOVA: $F=0.77, d f=4,324, p=0.54$

${ }^{a, b}$ Means with different superscript letters are significantly different at $p<.05$ 
Table 3

Proportion of Parks with Specific Facilities Per Census Tract by Income and Percent Minority

\begin{tabular}{|c|c|c|c|c|c|c|c|c|}
\hline $\begin{array}{c}\text { Tract } \\
\text { Characteristic }\end{array}$ & $\begin{array}{l}\text { Playground } \\
\text { Mean } \\
(\mathrm{SD})\end{array}$ & $\begin{array}{l}\text { Sports } \\
\text { Field } \\
\text { Mean } \\
(\mathrm{SD}) \\
\end{array}$ & $\begin{array}{l}\text { Baseball } \\
\text { Field } \\
\text { Mean } \\
\text { (SD) }\end{array}$ & $\begin{array}{c}\text { Swimming } \\
\text { Pool } \\
\text { Mean } \\
(\mathrm{SD}) \\
\end{array}$ & $\begin{array}{c}\text { Basketball } \\
\text { Court } \\
\text { Mean } \\
(\mathrm{SD}) \\
\end{array}$ & $\begin{array}{c}\text { Tennis } \\
\text { Court } \\
\text { Mean } \\
(\mathrm{SD}) \\
\end{array}$ & $\begin{array}{c}\text { Trail } \\
\text { Mean } \\
(\mathrm{SD}) \\
\end{array}$ & $\begin{array}{l}\text { Lake } \\
\text { Mean } \\
(\mathrm{SD})\end{array}$ \\
\hline \multicolumn{9}{|l|}{ Income $^{1}$} \\
\hline Low & $\begin{array}{l}0.62^{\mathrm{a}} \\
(0.40)\end{array}$ & $\begin{array}{c}0.18 \\
(0.34)\end{array}$ & $\begin{array}{c}0.47 \\
(0.43)\end{array}$ & $\begin{array}{c}0.12 \\
(0.27)\end{array}$ & $\begin{array}{c}0.51 \\
(0.44)\end{array}$ & $\begin{array}{c}0.28 \\
(0.39)\end{array}$ & $\begin{array}{c}0.49 \\
(0.41)\end{array}$ & $\begin{array}{c}0.15 \\
(0.29)\end{array}$ \\
\hline Medium & $\begin{array}{l}0.52^{\mathrm{a}} \\
(0.41)\end{array}$ & $\begin{array}{c}0.19 \\
(0.32)\end{array}$ & $\begin{array}{c}0.42 \\
(0.42)\end{array}$ & $\begin{array}{c}0.12 \\
(0.29)\end{array}$ & $\begin{array}{c}0.33 \\
(0.42)\end{array}$ & $\begin{array}{c}0.27 \\
(0.39)\end{array}$ & $\begin{array}{c}0.50 \\
(0.43)\end{array}$ & $\begin{array}{c}0.22 \\
(0.36)\end{array}$ \\
\hline High & $\begin{array}{c}0.69^{b} \\
(0.38)\end{array}$ & $\begin{array}{c}0.19 \\
(0.36)\end{array}$ & $\begin{array}{c}0.36 \\
(0.40)\end{array}$ & $\begin{array}{c}0.06 \\
(0.15)\end{array}$ & $\begin{array}{c}0.15 \\
(0.32)\end{array}$ & $\begin{array}{c}0.23 \\
(0.33)\end{array}$ & $\begin{array}{c}0.54 \\
(0.41)\end{array}$ & $\begin{array}{c}0.11 \\
(0.25)\end{array}$ \\
\hline$F$ & 4.88 & 0.95 & 0.36 & 0.57 & 0.08 & 0.76 & 0.38 & 1.52 \\
\hline df & 2,113 & 2,113 & 2,113 & 2,113 & 2,113 & 2,113 & 2,113 & 2,113 \\
\hline $\mathrm{p}$ & 0.01 & 0.39 & 0.70 & 0.57 & 0.93 & 0.47 & 0.69 & 0.22 \\
\hline \multicolumn{9}{|c|}{ Percent Minority ${ }^{2}$} \\
\hline High & $\begin{array}{c}0.67 \\
(0.39)\end{array}$ & $\begin{array}{c}0.15 \\
(0.31)\end{array}$ & $\begin{array}{c}0.49 \\
(0.42)\end{array}$ & $\begin{array}{c}0.12 \\
(0.27)\end{array}$ & $\begin{array}{l}0.59^{a} \\
(0.43)\end{array}$ & $\begin{array}{c}0.33 \\
(0.41)\end{array}$ & $\begin{array}{l}0.39^{\mathrm{a}} \\
(0.41)\end{array}$ & $\begin{array}{c}0.18 \\
(0.32)\end{array}$ \\
\hline Medium & $\begin{array}{c}0.57 \\
(0.39)\end{array}$ & $\begin{array}{c}0.24 \\
(0.33)\end{array}$ & $\begin{array}{c}0.34 \\
(0.38)\end{array}$ & $\begin{array}{c}0.11 \\
(0.27)\end{array}$ & $\begin{array}{l}0.30^{b} \\
(0.40)\end{array}$ & $\begin{array}{c}0.27 \\
(0.38)\end{array}$ & $\begin{array}{c}0.55^{b} \\
(0.41)\end{array}$ & $\begin{array}{c}0.21 \\
(0.33)\end{array}$ \\
\hline Low & $\begin{array}{l}0.55 \\
(0.42)\end{array}$ & $\begin{array}{c}0.18 \\
(0.36)\end{array}$ & $\begin{array}{c}0.43 \\
(0.43)\end{array}$ & $\begin{array}{c}0.08 \\
(0.21)\end{array}$ & $\begin{array}{l}0.13^{6} \\
(0.29)\end{array}$ & $\begin{array}{c}0.17 \\
(0.32)\end{array}$ & $\begin{array}{l}0.60^{b} \\
(0.41)\end{array}$ & $\begin{array}{c}0.10 \\
(0.27)\end{array}$ \\
\hline $\mathrm{F}$ & 2.98 & 0.77 & 1.36 & 0.04 & 5.18 & 1.59 & 5.61 & 0.56 \\
\hline df & 2,113 & 2,113 & 2,113 & 2,113 & 2,113 & 2,113 & 2,113 & 2,113 \\
\hline $\mathrm{p}$ & 0.06 & 0.47 & 0.26 & 0.96 & 0.01 & 0.21 & 0.01 & 0.58 \\
\hline
\end{tabular}

${ }^{1}$ MANCOVA: $\mathrm{F}=0.56, \mathrm{df}=4,224, \mathrm{p}=0.70$

${ }^{2}$ MANCOVA: $F=0.37, d f=4,226, p=0.83$

$a, b$ Means with different superscript letters were significantly different at $p<.05$ 
Table 4

Proportion of Parks with Neighborhood Amenities Per Census Tract by Income and Percent Minority

\begin{tabular}{|c|c|c|c|c|c|}
\hline $\begin{array}{c}\text { Tract } \\
\text { Characteristic }\end{array}$ & $\begin{array}{c}\text { Transit } \\
\text { Mean } \\
\text { (SD) }\end{array}$ & $\begin{array}{l}\text { Car Parking } \\
\text { Mean } \\
\text { (SD) }\end{array}$ & $\begin{array}{c}\text { Sidewalk } \\
\text { Mean } \\
\text { (SD) }\end{array}$ & $\begin{array}{c}\text { External } \\
\text { Trail } \\
\text { Mean } \\
\text { (SD) }\end{array}$ & $\begin{array}{c}\text { Traffic } \\
\text { Signa } \\
\text { Mean } \\
(\mathrm{SD})\end{array}$ \\
\hline \multicolumn{6}{|l|}{ Income $^{1}$} \\
\hline Low & $\begin{array}{c}0.70 \\
(0.42)\end{array}$ & $\begin{array}{c}0.90 \\
(0.27)\end{array}$ & $\begin{array}{r}0.87^{a} \\
(0.28)\end{array}$ & $\begin{array}{c}0.07 \\
(0.20)\end{array}$ & $\begin{array}{c}0.86 \\
(0.26)\end{array}$ \\
\hline Medium & $\begin{array}{c}0.54 \\
(0.46)\end{array}$ & $\begin{array}{c}0.91 \\
(0.22)\end{array}$ & $\begin{array}{l}0.61^{6} \\
(0.43)\end{array}$ & $\begin{array}{l}0.08 \\
(0.22)\end{array}$ & $\begin{array}{c}0.74 \\
(0.39)\end{array}$ \\
\hline High & $\begin{array}{c}0.29 \\
(0.43)\end{array}$ & $\begin{array}{c}0.87 \\
(0.27)\end{array}$ & $\begin{array}{c}0.74^{a} \\
(0.38)\end{array}$ & $\begin{array}{c}0.12 \\
(0.22)\end{array}$ & $\begin{array}{c}0.63 \\
(0.43)\end{array}$ \\
\hline $\mathrm{F}$ & 0.68 & 0.13 & 5.13 & 0.65 & 2.46 \\
\hline$d f$ & 2,113 & 2,113 & 2,113 & 2,113 & 2,113 \\
\hline $\mathrm{p}$ & 0.51 & 0.88 & 0.01 & 0.53 & 0.09 \\
\hline \multicolumn{6}{|c|}{ Percent Minority ${ }^{2}$} \\
\hline High & $\begin{array}{c}0.69 \\
(0.42)\end{array}$ & $\begin{array}{c}0.93 \\
(0.23)\end{array}$ & $\begin{array}{c}0.82 \\
(0.34)\end{array}$ & $\begin{array}{c}0.06 \\
(0.18)\end{array}$ & $\begin{array}{c}0.84 \\
(0.31)\end{array}$ \\
\hline Medium & $\begin{array}{c}0.51 \\
(0.46)\end{array}$ & $\begin{array}{c}0.83 \\
(0.31)\end{array}$ & $\begin{array}{c}0.66 \\
(0.40)\end{array}$ & $\begin{array}{c}0.10 \\
(0.24)\end{array}$ & $\begin{array}{c}0.67 \\
(0.39)\end{array}$ \\
\hline Low & $\begin{array}{l}0.38 \\
(0.45)\end{array}$ & $\begin{array}{c}0.92 \\
(0.20)\end{array}$ & $\begin{array}{c}0.74 \\
(0.40)\end{array}$ & $\begin{array}{c}0.11 \\
(0.22)\end{array}$ & $\begin{array}{l}0.75 \\
(0.38)\end{array}$ \\
\hline $\mathrm{F}$ & 0.93 & 1.31 & 1.63 & 0.19 & 1.76 \\
\hline$d f$ & 2,113 & 2,113 & 2,113 & 2,113 & 2,113 \\
\hline$p$ & 0.40 & 0.27 & 0.20 & 0.83 & 0.18 \\
\hline
\end{tabular}

${ }^{1}$ MANCOVA: $F=0.85, d f=10,218, p=0.05$

${ }^{2}$ MANCOVA: $F=1.10, d f=10,218, p=0.36$

$a, b$ Means with different superscript letters were significantly different at $p<.05$ 
Table 5

Proportion of Parks with Quality Amenities Per Census Tract by Income and Percent Minority

\begin{tabular}{|c|c|c|c|c|c|c|c|c|c|c|}
\hline Tract & Restrooms & $\begin{array}{l}\text { Drinking } \\
\text { Fountains }\end{array}$ & Benches & $\begin{array}{l}\text { Picnic } \\
\text { Tables }\end{array}$ & $\begin{array}{l}\text { Picnic } \\
\text { Shelters }\end{array}$ & Grills & $\begin{array}{l}\text { Trash } \\
\text { Cans }\end{array}$ & Shade & $\begin{array}{c}\text { Rules } \\
\text { About } \\
\text { Animals }\end{array}$ & $\begin{array}{c}\text { Animal } \\
\text { Waste } \\
\text { Bags }\end{array}$ \\
\hline & Mean (SD) & $\begin{array}{l}\text { Mean } \\
(\mathrm{SD})\end{array}$ & $\begin{array}{l}\text { Mean } \\
(\mathrm{SD})\end{array}$ & $\begin{array}{l}\text { Mean } \\
\text { (SD) }\end{array}$ & $\begin{array}{l}\text { Mean } \\
(\mathrm{SD})\end{array}$ & $\begin{array}{c}\text { Mean } \\
(\mathrm{SD})\end{array}$ & $\begin{array}{l}\text { Mean } \\
\text { (SD) }\end{array}$ & $\begin{array}{l}\text { Mean } \\
(\mathrm{SD})\end{array}$ & $\begin{array}{l}\text { Mean } \\
(\mathrm{SD})\end{array}$ & $\begin{array}{c}\text { Mean } \\
\text { (SD) }\end{array}$ \\
\hline \multicolumn{11}{|l|}{ Income $^{1}$} \\
\hline Low & $\begin{array}{c}0.22 \\
(0.37)\end{array}$ & $\begin{array}{c}0.39 \\
(0.41)\end{array}$ & $\begin{array}{c}0.76 \\
(0.34)\end{array}$ & $\begin{array}{c}0.65 \\
(0.42)\end{array}$ & $\begin{array}{c}0.30 \\
(0.39)\end{array}$ & $\begin{array}{c}0.34 \\
(0.41)\end{array}$ & $\begin{array}{c}0.78 \\
(0.35)\end{array}$ & $\begin{array}{c}0.42 \\
(0.42)\end{array}$ & $\begin{array}{c}0.10 \\
(0.27)\end{array}$ & $\begin{array}{c}0.06 \\
(0.22)\end{array}$ \\
\hline High & $\begin{array}{c}0.32 \\
(0.37)\end{array}$ & $\begin{array}{c}0.51 \\
(0.44)\end{array}$ & $\begin{array}{c}0.70 \\
(0.37)\end{array}$ & $\begin{array}{c}0.66 \\
(0.39)\end{array}$ & $\begin{array}{c}0.38 \\
(0.42)\end{array}$ & $\begin{array}{c}0.44 \\
(0.43)\end{array}$ & $\begin{array}{c}0.75 \\
(0.35)\end{array}$ & $\begin{array}{c}0.55 \\
(0.43)\end{array}$ & $\begin{array}{c}0.29 \\
(0.38)\end{array}$ & $\begin{array}{c}0.26 \\
(0.38)\end{array}$ \\
\hline $\mathrm{F}$ & 0.11 & 0.03 & 0.24 & 0.04 & 1.25 & 0.59 & 0.52 & 0.24 & 1.55 & 0.68 \\
\hline df & 2,113 & 2,113 & 2,113 & 2,113 & 2,113 & 2,113 & 2,113 & 2,113 & 2,113 & 2,113 \\
\hline Medium & $\begin{array}{c}0.27 \\
(0.33)\end{array}$ & $\begin{array}{c}0.44 \\
(0.42)\end{array}$ & $\begin{array}{c}0.70 \\
(0.39)\end{array}$ & $\begin{array}{c}0.57 \\
(0.42)\end{array}$ & $\begin{array}{c}0.28 \\
(0.36)\end{array}$ & $\begin{array}{c}0.34 \\
(0.37)\end{array}$ & $\begin{array}{c}0.71 \\
(0.34)\end{array}$ & $\begin{array}{c}0.52 \\
(0.41)\end{array}$ & $\begin{array}{c}0.11 \\
(0.26)\end{array}$ & $\begin{array}{c}0.10 \\
(0.28)\end{array}$ \\
\hline Low & $\begin{array}{c}0.34 \\
(0.40)\end{array}$ & $\begin{array}{c}0.55 \\
(0.42)\end{array}$ & $\begin{array}{c}0.71 \\
(0.39)\end{array}$ & $\begin{array}{c}0.71 \\
(0.38)\end{array}$ & $\begin{array}{c}0.31 \\
(0.42)\end{array}$ & $\begin{array}{c}0.39 \\
(0.45)\end{array}$ & $\begin{array}{c}0.81 \\
(0.33)\end{array}$ & $\begin{array}{c}0.51 \\
(0.43)\end{array}$ & $\begin{array}{c}0.26 \\
(0.38)\end{array}$ & $\begin{array}{c}0.29 \\
(0.41)\end{array}$ \\
\hline $\mathrm{F}$ & 2.45 & 1.65 & 1.04 & 0.85 & 0.14 & 0.24 & 0.84 & 0.42 & 0.36 & 1.30 \\
\hline$d f$ & 2,113 & 2,113 & 2,113 & 2,113 & 2,113 & 2,113 & 2,113 & 2,113 & 2,113 & 2,113 \\
\hline$p$ & 0.09 & 0.20 & 0.36 & 0.43 & 0.87 & 0.78 & 0.44 & 0.66 & 0.70 & 0.28 \\
\hline
\end{tabular}

${ }^{1}$ MANCOVA: $F=0.51, d f=20,208, p=0.96$

${ }^{2}$ MANCOVA: $F=1.59, \mathrm{df}=20,208, p=0.05$ 
Table 6

Proportion of Parks with Safety Amenities Per Census Tract by Income and Percent Minority

\begin{tabular}{|c|c|c|c|c|c|c|}
\hline $\begin{array}{c}\text { Tract } \\
\text { Characteristic }\end{array}$ & $\begin{array}{l}\text { Lights } \\
\text { Mean } \\
(\mathrm{SD})\end{array}$ & $\begin{array}{l}\text { Park } \\
\text { Monitored } \\
\text { Mean } \\
(\text { SD) } \\
\end{array}$ & $\begin{array}{l}\text { Dangerous } \\
\text { Spots } \\
\text { Mean } \\
\text { (SD) } \\
\end{array}$ & $\begin{array}{l}\text { Threatening } \\
\text { Behaviors } \\
\text { Mean } \\
\text { (SD) }\end{array}$ & $\begin{array}{l}\text { Neighborhood } \\
\text { Visibility } \\
\text { Mean } \\
\text { (SD) }\end{array}$ & $\begin{array}{l}\text { Road } \\
\text { Through } \\
\text { Park } \\
\text { Mean } \\
\text { (SD) } \\
\end{array}$ \\
\hline \multicolumn{7}{|l|}{ Income $^{1}$} \\
\hline Low & $\begin{array}{c}0.48 \\
(0.45)\end{array}$ & $\begin{array}{c}0.17 \\
(0.29)\end{array}$ & $\begin{array}{c}0.29 \\
(0.39)\end{array}$ & $\begin{array}{c}0.13 \\
(0.28)\end{array}$ & $\begin{array}{c}0.68 \\
(0.42)\end{array}$ & $\begin{array}{c}0.35 \\
(0.41)\end{array}$ \\
\hline Medium & $\begin{array}{c}0.41 \\
(0.42)\end{array}$ & $\begin{array}{c}0.07 \\
(0.22)\end{array}$ & $\begin{array}{c}0.35 \\
(0.44)\end{array}$ & $\begin{array}{c}0.03 \\
(0.18)\end{array}$ & $\begin{array}{c}0.72 \\
(0.40)\end{array}$ & $\begin{array}{c}0.22 \\
(0.35)\end{array}$ \\
\hline High & $\begin{array}{l}0.63 \\
(0.41)\end{array}$ & $\begin{array}{c}0.18 \\
(0.32)\end{array}$ & $\begin{array}{l}0.23 \\
(0.35)\end{array}$ & $\begin{array}{l}0.15 \\
(0.32)\end{array}$ & $\begin{array}{c}0.53 \\
(0.46)\end{array}$ & $\begin{array}{c}0.32 \\
(0.39)\end{array}$ \\
\hline $\mathrm{F}$ & 1.37 & 0.24 & 0.20 & 0.35 & 1.59 & 1.45 \\
\hline $\mathrm{df}$ & 2,113 & 2,113 & 2,113 & 2,113 & 2,113 & 2,113 \\
\hline $\mathrm{p}$ & 0.26 & 0.79 & 0.82 & 0.70 & 0.21 & 0.24 \\
\hline \multicolumn{7}{|c|}{ Percent Minority ${ }^{2}$} \\
\hline High & $\begin{array}{c}0.62 \\
(0.41)\end{array}$ & $\begin{array}{c}0.22 \\
(0.36)\end{array}$ & $\begin{array}{c}0.25 \\
(0.36)\end{array}$ & $\begin{array}{c}0.18 \\
(0.35)\end{array}$ & $\begin{array}{c}0.60 \\
(0.45)\end{array}$ & $\begin{array}{c}0.36 \\
(0.42)\end{array}$ \\
\hline Medium & $\begin{array}{c}0.46 \\
(0.44)\end{array}$ & $\begin{array}{c}0.15 \\
(0.24)\end{array}$ & $\begin{array}{c}0.29 \\
(0.37)\end{array}$ & $\begin{array}{c}0.09 \\
(0.25)\end{array}$ & $\begin{array}{c}0.65 \\
(0.43)\end{array}$ & $\begin{array}{c}0.21 \\
(0.32)\end{array}$ \\
\hline Low & $\begin{array}{c}0.47 \\
(0.44)\end{array}$ & $\begin{array}{c}0.07 \\
(0.20)\end{array}$ & $\begin{array}{c}0.31 \\
(0.43)\end{array}$ & $\begin{array}{l}0.05 \\
(0.19)\end{array}$ & $\begin{array}{c}0.66 \\
(0.44)\end{array}$ & $\begin{array}{c}0.34 \\
(0.41)\end{array}$ \\
\hline$F$ & 1.18 & 1.11 & 0.06 & 0.26 & 0.04 & 2.36 \\
\hline df & 2,113 & 2,113 & 2,113 & 2,113 & 2,113 & 2,113 \\
\hline$p$ & 0.31 & 0.33 & 0.94 & 0.77 & 0.96 & 0.10 \\
\hline
\end{tabular}

${ }^{1}$ MANCOVA: $\mathrm{F}=0.78, \mathrm{df}=12,216, \mathrm{p}=0.67$

${ }^{2}$ MANCOVA: $F=0.97, d f=12,216, p=0.48$ 
Table 7

Quality Concerns and Aesthetic Features Per Park by Income and Percent Minority

\begin{tabular}{|c|c|c|c|c|}
\hline \multirow{2}{*}{$\begin{array}{c}\text { Tract } \\
\text { Characteristic }\end{array}$} & \multicolumn{2}{|c|}{$\begin{array}{c}\text { Average Quality Concerns } \\
\text { Per Park }\end{array}$} & \multicolumn{2}{|c|}{$\begin{array}{c}\text { Average Aesthetic Features } \\
\text { Per Park }\end{array}$} \\
\hline & Mean & SD & Mean & SD \\
\hline \multicolumn{5}{|l|}{ Income $^{1}$} \\
\hline Low & $0.75^{a}$ & 0.89 & $2.11^{a, b}$ & 1.29 \\
\hline Medium & $0.50^{b}$ & 0.56 & $3.02^{\mathrm{a}}$ & 1.57 \\
\hline High & $0.42^{\mathrm{b}}$ & 0.57 & $2.29^{b}$ & 1.31 \\
\hline $\mathrm{F}$ & \multicolumn{2}{|c|}{3.74} & \multicolumn{2}{|c|}{6.08} \\
\hline df & \multicolumn{2}{|c|}{2,113} & \multicolumn{2}{|c|}{2,113} \\
\hline $\mathrm{p}$ & \multicolumn{2}{|c|}{0.03} & \multicolumn{2}{|c|}{$<.01$} \\
\hline \multicolumn{5}{|c|}{ Percent Minority ${ }^{2}$} \\
\hline High & 0.62 & 0.87 & 2.18 & 1.52 \\
\hline Medium & 0.57 & 0.65 & 2.65 & 1.41 \\
\hline Low & 0.57 & 0.71 & 2.68 & 1.39 \\
\hline $\mathrm{F}$ & \multicolumn{2}{|c|}{0.71} & \multicolumn{2}{|c|}{1.35} \\
\hline df & \multicolumn{2}{|c|}{2,113} & \multicolumn{2}{|c|}{2,113} \\
\hline $\mathrm{p}$ & \multicolumn{2}{|c|}{0.49} & \multicolumn{2}{|c|}{0.26} \\
\hline
\end{tabular}

${ }^{1}$ MANCOVA: $\mathrm{F}=4.84, \mathrm{df}=4,222, \mathrm{p}<.01$

${ }^{2}$ MANCOVA: $F=1.02, d f=4,224, p=0.40$

${ }^{a, b}$ Means with different superscript letters were significantly different at $p<.05$ 
Figure 1

Number of Parks by Census Tract Income

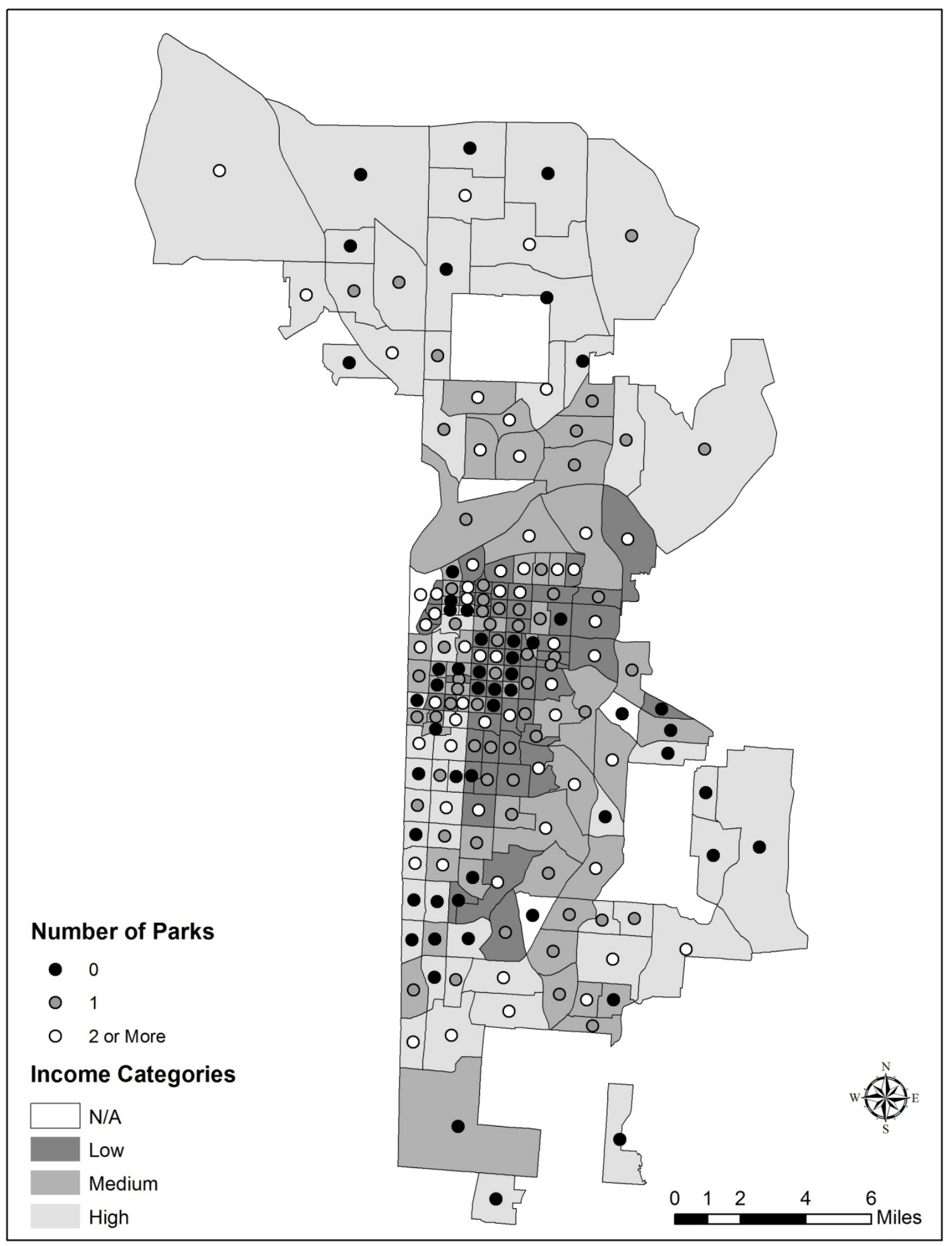

